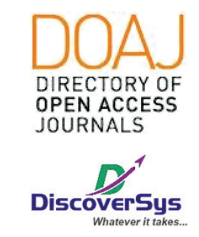

Published by DiscoverSys

\section{Anemia and metabolic acidosis are a predictor for mortality in children with severe acute malnutrition at Sanglah General Hospital, Bali}

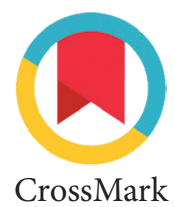

\author{
Ni Putu Andina Kluniari, ${ }^{*}$ I Gusti Lanang Sidiartha
}

\title{
ABSTRACT
}

Background: Severe acute malnutrition (SAM) is one of the leading causes of morbidity and mortality in children in developing countries. Nutritional disorders are frequent in hospitalized patients, of which malnutrition is the most prevalent Anemia and PH disturbance was commonly found in this condition. This study aims to determine the association between anemia and metabolic acidosis with the mortality among children with severe acute malnutrition.

Methods: A retrospective cohort study was conducted among 135 severe acute malnutrition children in the pediatric care unit of Sanglah General Hospital from the 2017-2018 period. The inclusion criteria were children aged 1 month to 18 years diagnosed with SAM. Exclusion criteria were a patient diagnosed with a hematological disorder or renal disorder. Data were analyzed using SPSS version 20 for Windows.

Results: Anemia was diagnosed in 89 (65.9\%) subjects in this study. Anemia increases the risk of death significantly by 3.98 times $(95 \% \mathrm{Cl}$ 2.167-10.389; $p<0.001)$. Metabolic acidosis was found in 35 (25.9\%) subjects; this condition was also shown to significantly increase the risk of death by 1.5 times ( $95 \% \mathrm{Cl} 1.005-2.145 ; \mathrm{p}=0.018)$.

Conclusion: Anemia and metabolic acidosis can be used as predictors for mortality in severe acute malnutrition patient significantly.
Department of Child Health, Faculty of Medicine, Universitas Udayana, Sanglah General Hospital, Bali, Indonesia
${ }^{*}$ Correspondence to: Ni Putu Andina Kluniari, Department of Child Health, Faculty of Medicine, Universitas Udayana, Sanglah General Hospital, Bali, Indonesia andinakluniari@gmail.com

Received: 2019-09-22 Accepted: 2020-06-02 Published: 2020-08-01
Keywords: Severe Acute Malnutrition, Anemia, Metabolic Acidosis, Mortality

Cite This Article: Kluniari, N.P.A., Sidiartha, I.G.L. 2020. Anemia and metabolic acidosis are a predictor for mortality in children with severe acute malnutrition at Sanglah General Hospital, Bali. Intisari Sains Medis 11(2): 620-624. D0I: 10.15562/ism.v11i2.627

\section{INTRODUCTION}

Childhood malnutrition is an important indicator of the health of a population. ${ }^{1}$ A worldwide analysis recently identified childhood malnutrition as the leading risk factor for the global burden of disease. ${ }^{1}$ Severe acute malnutrition (SAM) is one of the leading causes of morbidity and mortality in children in developing countries. ${ }^{1,2}$ Nutritional disorders are frequent in hospitalized patients, of which malnutrition is the most prevalent. ${ }^{2}$ In developed countries, the frequency of malnutrition among pediatric patients is around $24 \% .^{3}$ Surveys conducted over the past two decades report $15 \%$ to $65 \%$ malnutrition rates in pediatric patients admitted to the intensive care unit (ICU), with malnourished children presenting a higher incidence of both infection and mortality. ${ }^{4}$ Recent data have revealed that malnutrition in critically ill hospitalized children ranges from $10 \%$ to $24 \%$. However, no independent association with mortality has been found. ${ }^{5}$ In 2013 prevalence of severe acute malnutrition in Indonesia was 5,7\%. ${ }^{6}$

This condition that kills children and intellectually maims those who survive. The complications caused by malnutrition very diverse. These changes include lowered immune response, atrophy, and increased permeability of the intestinal epithelial barrier, which facilitates infection and bacterial translocation. ${ }^{7}$ Malnourished patients also suffer from more inadequate healing of wounds, higher incidence of pneumonia, sepsis, and other conditions that can lead to increased mortality, length of hospital stay, and health care costs. ${ }^{7-9}$ Malnutrition is responsible directly or indirectly for about $50 \%$ of deaths among children under five. Factors associated with mortality in children with severe acute malnutrition are blood glucose level, severe anemia, comorbidity, kwashiorkor as a type of SAM and dehydration. ${ }^{10,11}$

Anemia prevalence in children is high, especially in developing countries, and frequently is multifactorial. ${ }^{12}$ It is often associated with childhood malnutrition, producing interlinked factors, several of which could be causally related to mortality risk. These factors include lack of hematinic (e.g., iron, folate, vitamins A, B-12 and C, and copper), impairment of red cell production by acute or sub-acute inflammation (with an increase in stored iron) and increased red cell destruction either via specific infections (e.g., malaria) or particular nutrients (e.g., vitamin A). Research in India found a high incidence of severe anemia in SAM with a large proportion (25\%) of its requiring blood transfusion. ${ }^{2}$ The study in Nigeria also revealed high mortality rates among malnutrition children who with severe anemia. ${ }^{13}$ 
Severe acute malnutrition is a metabolic disorder characterized by profound disturbance of water, electrolytes, minerals, protein, fat, carbohydrates, and energy metabolism, along with disturbances in the function and composition of almost all tissues of the body. ${ }^{14}$ Nutrition has long been known to influence acid-base balance strongly. Malnutrition is a state of catabolism and severe malnutrition is a state of severe catabolism. In a healthy body, homeostasis is maintained mainly by kidney, lungs, minerals and body fluids, and it is altered in malnutrition. ${ }^{14}$

The severe malnutrition may lead to a persistent increase in acid load in the internal milieu of the body, disturbing the internal homeostasis. The normal function of all body cells depends on the regulation of acid-base balance. Arterial Blood Gas $(A B G)$ studies are concerned with respiration, the exchange of gases between the lungs and blood, and between blood and tissues. ${ }^{15}$ By analyzing the ABG of malnourished children, it can be ascertained whether any change in the acid-base balance is one of the factors besides many others for the increased morbidity and mortality in the children suffering from acute malnutrition. Study of 85 hospitalized severely malnourished patients have reported metabolic acidosis were in $35.29 \%$, and 12 of them has a distal renal tubular acidosis which confirms the findings by other researchers Research also found, that acidosis can increase the mortality risk in malnourish children. ${ }^{16}$

Based on those mentioned above, this study aims to determine the hemoglobin and blood gas analysis as a predictor of mortality patients with severe acute malnutrition.

\section{METHODS}

This study used a retrospective cohort design study during the 2017 - 2018 period on severe acute malnutrition children in the pediatric care unit of Sanglah Denpasar General Hospital. Severe acute malnutrition is defined by very low weight for height (below $-3 z$ scores of the median WHO growth standards), or mid-upper-arm circumference (MUAC) $<115 \mathrm{~mm}$ or the presence of bilateral pitting edema, or both.

The subject of this study was all patients diagnoses with severe acute malnourished who were admitted to the pediatric care unit of Sanglah Hospital among the study period. Inclusion criteria were children aged 1 month to 18 years diagnosed with SAM, and patients had complete data at the start of admission. Exclusion criteria were a patient diagnosed with the hematological disorder and or a renal disorder. The respondents are determined by taking the subject in sequence until the number of subjects is met.
The estimated required sample using the sample formula for a cohort retrospective study was found 50 people for each group. The total needed minimal sample was 100 people. Patients who met the previously mentioned inclusion and exclusion criteria were included in the study. Each subject is then given an identity number and recorded as initials following applicable codes of ethics.

Data of each patient who had been included in the study, prospectively taken in the form of identity, age, diagnosis, gender, hemoglobin level, acidbase status using blood gas analysis, albumin level, and blood sugar level at admission. The analysis was done to determine whether hemoglobin level and acidosis metabolic as predictors of mortality in subjects with severe acute malnutrition. Anemia can be defined as a reduction in red blood cell mass or blood hemoglobin concentration. Anemia measured using WHO's criterion for anemia in children. Children under 5 years old with hemoglobin $(\mathrm{Hb})$ levels $<11 \mathrm{~g} / \mathrm{dL}$ and $\mathrm{Hb}$ level $<12$ for older children. Acidosis metabolic was as an arterial $\mathrm{pH}$ below the normal range due to a fall in serum bicarbonate concentration. Diagnosed using blood gas analysis when the $\mathrm{PH}<7.35$ and $\mathrm{HCO} 3$ $<22 \mathrm{mmol} / \mathrm{L}$. The outcome is determined by death or survive

Data obtained from the sample then collected and processed into SPSS version 20 for Windows, descriptive analysis used to describe the characteristics of research subjects based on the outcome so that it can be assessed comparability between the two groups. The analysis to evaluate the association between variables as predictors to mortality in SAM and mortality was done by making a $2 \times 2$ cross-tabulation (dummy table). The statistical test used is the chi-square test with the significance limit of 0.05 . A p-value of less than 0.25 was included in multivariate analysis. The analysis used is logistic regression, statistically significant with $95 \%$ confidence interval $(\mathrm{CI})$ and $\mathrm{P}$ values $<0.05$.

\section{RESULTS}

The study collected as many as 135 subjects with severely malnourished included in this study since 2017 - 2018. We manage 61 subjects as a death group and 74 subjects as control. The majority of subjects were male (57.8\%) and younger than 5 years old (59.3\%). The subject with anemia was $89(65.9 \%)$ children. From blood gas analysis, we found 35 (25.9\%) subjects suffering from metabolic acidosis. The characteristics and laboratory findings were summarized in Table 1.

The predictors for mortality in SAM were summarized in Table 2. There was a statistically significant difference between death and survival 
Table 1 Baseline Characteristics of Respondents

\begin{tabular}{|c|c|}
\hline Characteristic & $\mathrm{N}=135$ \\
\hline \multicolumn{2}{|l|}{ Sex, n (\%) } \\
\hline Male & $78(57.8)$ \\
\hline Female & $57(42.2)$ \\
\hline \multicolumn{2}{|l|}{ Age, n (\%) } \\
\hline$<5$ years & $80(59,3)$ \\
\hline$>5$ years & $55(40,7)$ \\
\hline $\mathrm{Hb}(\mathrm{g} / \mathrm{dL})($ mean $\pm \mathrm{SD})$ & $10.07 \pm 2.8$ \\
\hline \multicolumn{2}{|l|}{ Anemia, n (\%) } \\
\hline Yes & $89(65.9)$ \\
\hline No & $46(34.1)$ \\
\hline $\mathrm{pH}(\mathrm{mean} \pm \mathrm{SD})$ & $7.36 \pm 0.35$ \\
\hline $\mathrm{HCO} 3(\mathrm{mmol} / \mathrm{L})(\mathrm{mean} \pm \mathrm{SD})$ & $22.99 \pm 8.6$ \\
\hline \multicolumn{2}{|l|}{ Metabolic acidosis, n (\%) } \\
\hline Yes & $35(25.9)$ \\
\hline No & $100(74.1)$ \\
\hline \multicolumn{2}{|l|}{ Type of SAM, n (\%) } \\
\hline Kwashiorkor & $2(1.5)$ \\
\hline Marasmus & $133(98.5)$ \\
\hline \multicolumn{2}{|l|}{ Condition, n (\%) } \\
\hline 1 & $10(7.4)$ \\
\hline 2 & $1(0.7)$ \\
\hline 3 & $26(19.3)$ \\
\hline 4 & $3(2.2)$ \\
\hline 5 & $95(70.4)$ \\
\hline
\end{tabular}

Hb: hemoglobin; SAM: severe acute malnutrition

Table 2 Predictors for Mortality in SAM

\begin{tabular}{|c|c|c|c|}
\hline Variables & Death $(\mathrm{N}=61)$ & Survive $(\mathrm{N}=74)$ & $\mathbf{p}$ \\
\hline \multicolumn{4}{|l|}{ Sex, n (\%) } \\
\hline Male & $38(62.3)$ & $40(54.1)$ & 0.335 \\
\hline Female & $23(37.3)$ & $34(45.9)$ & \\
\hline \multicolumn{4}{|l|}{ Age (years), n (\%) } \\
\hline$<5$ & $31(50.8)$ & $49(66.2)$ & 0.070 \\
\hline$>5$ & $30(49.2)$ & $25(33.8)$ & \\
\hline \multicolumn{4}{|l|}{ Type of SAM, n (\%) } \\
\hline Marasmus & $61(100.0)$ & $72(97.3)$ & 0.196 \\
\hline Kwashiorkor & $0(0.0)$ & $2(2.7)$ & \\
\hline \multicolumn{4}{|l|}{ Hemoglobin Status, n (\%) } \\
\hline Anemia & $54(88.5)$ & $35(47.3)$ & $0.0001^{\star}$ \\
\hline No anemia & $7(11.5)$ & $39(52.7)$ & \\
\hline \multicolumn{4}{|l|}{ Blood Gas Analysis, n (\%) } \\
\hline Metabolic acidosis & $21(34.4)$ & $14(18.9)$ & $0.041^{*}$ \\
\hline No metabolic acidosis & $40(65.6)$ & $60(81.1)$ & \\
\hline
\end{tabular}

SAM: severe acute malnutrition; ${ }^{\star} P$-value was considered statistically significant if less than 0.05 cases with the hemoglobin status $(\mathrm{p}=0.0001)$ and Blood Gas Analysis ( $\mathrm{p}=0.041$ ) (Table 2). In subjects with anemia, the mortality rate was $88.5 \%$. In the subject with metabolic acidosis, the mortality was $34.4 \%$ (Table 2).

The risk of age, sex, anemia, and metabolic acidosis for mortality children with severe malnutrition was analyzed in Table 3 . The multivariate analysis found significant variables in anemia $(\mathrm{p}=0.001)$ and metabolic acidosis $(\mathrm{p}=0.018)$ variables with the risk of mortality (Table 3 ).

\section{DISCUSSION}

Protein Energy Malnutrition (PEM) is defined as a spectrum of diseases arising as a result of an absolute or relative deficiency of calories and/or protein in the diet. Malnutrition is one of the significant causes of childhood morbidity and mortality. This condition is still a significant challenge in developing nations, were in 2011 about for 3.1 million or $45 \%$ of all child deaths causes by this condition. ${ }^{17}$

The majority of subjects were younger than 5 years old. Globally, approximately 19 million children under 5 years are suffering from Severe Acute Malnutrition (SAM) in 2015. ${ }^{18}$ The mortality rate in children with SAM is nine times more likely to die as compared to healthy children. Mortality rates as low as $2.2 \%$ in India and as high as $42 \%$ in Malawi were observed among children treated in the stabilization center. ${ }^{18}$

Anemia can be defined as a reduction in red blood cell mass or blood hemoglobin concentration. In practice, anemia is most commonly defined by reductions in one or more of the following; chronic infection and diseases (including HIV Infection); poor nutrition; autoimmune diseases; adverse drug effects; blood loss, especially chronic blood loss; hemolysis. ${ }^{19}$ Anemia is common between severely malnourished children and severe anemia is a medical emergency ${ }^{19,20}$ This study found the prevalence of anemia among children with severe acute malnutrition was $65,9 \%$ with mean hemoglobin levels were $10,07 \mathrm{mg} / \mathrm{dL}$. Anemia was significantly associated with malnutrition status. ${ }^{21}$ Other studies in India found a similar result, a very high percentage of malnourished children were found to be anemic. ${ }^{12,22}$ From the study population, 118 children $(90 \%)$ children were anemic. Seventy-nine (67\%) had severe anemia, 17 (14\%) had moderate anemia, and $22(19 \%)$ had mild anemia. One-fourth of the children with anemia required blood transfusion. The most common type of anemia was microcytic, followed by megaloblastic. Mothers also were anemic, with mean $\mathrm{Hb} 9.1 \mathrm{~g} / \mathrm{dL} .^{12}$ The latest study of 200 cases of severe acute malnutrition found that 
Table 3 Multivariate analysis factors associated with SAM

\begin{tabular}{lccc}
\hline Variable & Exp (B) & $\mathbf{9 5 \% ~ C l}$ & p \\
\hline Age & 0.49 & $0.219-1.107$ & 0.087 \\
Sex & 0.11 & $0.850-4.320$ & 0.117 \\
Anemia & 3.98 & $2.167-10.389$ & $0.001^{\star}$ \\
Metabolic acidosis & 1.51 & $1.005-2.145$ & $0.018^{\star}$ \\
\hline
\end{tabular}

Exp (B): exponent $B$; CI: confidence interval

95\% children had anemia, out of which $8(4 \%)$ cases had mild Anemia, 92 (46\%) cases had moderate anemia, and 90 (45\%) cases had severe anemia. ${ }^{22}$ Most of the cases had hypochromic microcytic type anemia. ${ }^{22}$ Our study cannot describe the type of anemia due to data limitation in the morphological state for the red blood cell. From this finding, we conclude that poor nutrition was the leading cause of anemia in severe acute malnutrition.

In this study, among 61 children who were dead, 54 children $(88,5 \%)$ had abnormal hemoglobin levels. From statistical analysis, anemia was strongly associated with mortality, indicates 3.98 times higher risk of death in children with abnormal hemoglobin levels compared with children who had average hemoglobin level. A study from Roy et all in 2011 showed anemia were significantly more likely to die during treatment compared to patients without anemia. ${ }^{23}$ The study revealed patients with severe anemia 4,2 times riskier to death based considerably on the previous study. ${ }^{23}$ Newest research in Ethiopia showed the same result. Anemia was shown to increase the mortality risk of children with severe acute malnutrition by 2.3 times with AHR (Adjusted Hazard Ratio): 2.3, and $95 \%$ CI: $1.2-4.5 .{ }^{18}$ Different results found by Savadogo et all in Burkina Faso at 2014 where there is no association between the deaths of children suffering from severe malnutrition and anemia. During hospitalization, the case fatality rate was $13.9 \% .{ }^{24}$ The mortality rate did not differ significantly from severely malnourished children with anemia at admission and severely malnourished children without anemia at admission. ${ }^{24}$ Statistical analysis in his research also showed relative mortality risk was $0.56,95 \% \mathrm{CI}=[0.28-1.14]$, for severely malnourished children with anemia at admission. Kaplan Meir's survival curves also did not differ significantly between the two groups ( $p$ Log Rank $=0.11) .{ }^{24}$ The finding of this study that abnormal hemoglobin level risk factors for poor outcomes among severely malnourished children agreed with those previously reported by other authors.

Malnutrition, as mentioned earlier, is a state of catabolism. The severe malnutrition may lead to a persistent increase in acid load that can affect the normal function of all body cells. ${ }^{14}$ The kidneys, lungs, and blood buffers can usually balance acids and bases. Arterial Blood Gas (ABG) studies are concerned with respiration, the exchange of gases between the lungs and blood and between blood and tissues. Analyzing the ABG of malnourished children can be ascertained whether any change in the acid-base balance is one of the factors besides many others for the increased morbidity and mortality in the children suffering from SAM. ${ }^{14}$

Metabolic acidosis is the most common disorder encountered in clinical practice. ${ }^{25}$ A study noted that about $56.3 \%$ of patients with severe acute malnutrition had metabolic acidosis. ${ }^{26}$ Another study conducted to assess the relationship between electrolyte abnormalities and mortality observed electrolyte disturbance in $80 \%$ of patients while acid-base disturbance was observed in all patients. ${ }^{27,28}$ The prevalence of metabolic acidosis in this study found in 25 subjects (35,9\%).

Statistical analysis of the relationship between mortality and metabolic acidosis in malnourished patients in this study found a relationship between the two. Malnutrition sufferers who have metabolic acidosis have a risk of death 1.5 times higher than those who do not suffer from metabolic acidosis. The mortality rate of all the SAM patients from research in India was 4\% (4/100). A previous study found that $\mathrm{pH}<7.35$ found no mortality in the groups of normal $\mathrm{pH}$ and $\mathrm{pH}>7.45$, this indicate metabolic acidosis was significantly associated with mortality among SAM patients. ${ }^{5}$ Another study showed the same result. The mortality rate of all the SAM patients was $5.4 \%$.It was least $(1.1 \% ; n=1 / 88)$ in children with normal $\mathrm{pH}$, followed by $3.8 \%$ ( $\mathrm{n}=$ $3 / 80$ ) in those with $\mathrm{pH}>7.45$ and highest $(20.6 \%$; $\mathrm{n}=7 / 34)$ in those with $\mathrm{pH}<7.35$. This difference was statistically significant $(\mathrm{P}<0.0001) .{ }^{14}$

This study used a prospective observational design and conducted at a single center. Other Factors associated with mortality in patients diagnosed with severe acute malnutrition were not analyzed in this study. Further studies still needed to be done to overcome the limitation of this study.

\section{CONCLUSION}

Anemia and metabolic acidosis were a common condition that can be found in malnutrition patients. Anemia and metabolic acidosis are predictor mortality in SAM.

\section{CONFLICT OF INTEREST}

There is no competing interest regarding the manuscript. 


\section{ETHICS CONSIDERATION}

The research conducted after the approval of the Ethics Committee of Medical Faculty of Medicine/ Sanglah Hospital. Ethical approval no. 2392/ UN14.2.2.VII.14/LP/2019.

\section{FUNDING}

None.

\section{AUTHOR CONTRIBUTION}

Both authors are equally contributing to the study from the conceptual framework, data gathering, data analysis, until presenting the results through publication.

\section{REFERENCES}

1. Ahmed T, Hossain M, Mahfuz M, Choudhury N, Hossain MM, Bhandari N et al. Severe acute malnutrition in Asia. Food Nutr Bull. 2014;35(2 Suppl):S14-S26.

2. Norman K, Pichard C, Lochs H, Pirlich M. Prognostic impact of disease-related malnutrition. Clin Nutr. 2008;27(1):5-15.

3. Pawellek I, Dokoupil K, Koletzko B. Prevalence of malnutrition in paediatric hospital patients. Clin Nutr. 2008;27(1):72-76

4. Briassoulis G, Zavras N, Hatzis T. Malnutrition, nutritional indices, and early enteral feeding in critically ill children. Nutrition. 2001;17(7-8):548-557.

5. Hulst J, Joosten K, Zimmermann L, Hop W, van Buuren S, Büller $\mathrm{H}$ et al. Malnutrition in critically ill children: from admission to 6 months after discharge. Clin Nutr. 2004;23(2):223-232.

6. Riset Kesehatan Dasar. Penelitian dan Pengembangan Kesehatan Kementerian RI. 2013. [Available at: http:// www.depkes.go.id/resources/download/general/Hasil\%20 Riskesdas] [Accessed: February 19 ${ }^{\text {th }} 2018$ ].

7. Corish CA, Kennedy NP. Protein-energy undernutrition in hospital in-patients. Br J Nutr. 2000;83(6):575-591.

8. Bernstein LH, Shaw-Stiffel TA, Schorow M, Brouillette R. Financial implications of malnutrition. Clin Lab Med. 1993;13(2):491-507.

9. Correia MI, Waitzberg DL. The impact of malnutrition on morbidity, mortality, length of hospital stay and costs evaluated through a multivariate model analysis. Clin Nutr. 2003;22(3):235-239.

10. Jarso H, Workicho A, Alemseged F. Survival status and predictors of mortality in severely malnourished children admitted to Jimma University Specialized Hospital from 2010 to 2012, Jimma, Ethiopia: a retrospective longitudinal study. BMC Pediatr. 2015;15:76.

11. Desta KS. Survival Status and Predictors of Mortality among Children Aged 0-59 Months with Severe Acute Malnutrition Admitted to Stabilization Center at Sekota Hospital Waghemra Zone. J Nutr Disorders Ther. 2015;5:1-11.

12. Thakur N, Chandra J, Pemde H, Singh V. Anemia in severe acute malnutrition. Nutrition. 2014;30(4):440-442.
13. Muoneke VU, Ibekwe RC, Nebe-Agumadu HU, Ibe BC. Factors associated with mortality in under-five children with severe anemia in Ebonyi, Nigeria. Indian Pediatr. 2012;49(2):119-123.

14. Bartz S, Mody A, Hornik C, et al. Severe acute malnutrition in childhood: hormonal and metabolic status at presentation, response to treatment, and predictors of mortality. J Clin Endocrinol Metab. 2014;99(6):2128-2137.

15. Simpson $\mathrm{H}$. Interpretation of arterial blood gases: a clinical guide for nurses. Br J Nurs. 2004;13(9):522-528.

16. Ravanagomagan, Sethi RS, Sethi A, Chaurasiya OS. Metabolic Acidosis: An Important Morbidity in SAM Children. Int J Sci Res. 2017;10(1):21-4

17. Nurpalah R, Wahyuni D, Lutfiah E, Mariana L. Gambaran kadar glukosa, protein, dan natrium pada anak dengan status gizi buruk. Jurnal Kesehatan Bakti Tunas Husada. 2015;14(1):113-118.

18. Wagnew F, Tesgera D, Mekonnen M, Abajobir AA. Predictors of mortality among under-five children with severe acute malnutrition, Northwest Ethiopia: an institution based retrospective cohort study. Arch Public Health. 2018;76:64

19. Egata G, Berhane Y, Worku A. Predictors of acute undernutrition among children aged 6 to 36 months in east rural Ethiopia: a community based nested case - control study. BMC Pediatr. 2014;14:91.

20. Joosten KF, Hulst JM. Prevalence of malnutrition in pediatric hospital patients. Curr Opin Pediatr. 2008;20(5):590-596.

21. Yang W, Li X, Li Y, et al. Anemia, malnutrition and their correlations with socio-demographic characteristics and feeding practices among infants aged 0-18 months in rural areas of Shaanxi province in northwestern China: a cross-sectional study. BMC Public Health. 2012;12:1127.

22. Arya AK, Kumar P, Midha T, Singh M. Hematological profile of children with severe acute malnutrition: a tertiary care centre experience. Int J Contemp Pediatr. 2017;4(5):1577-80

23. Roy SK, Buis M, Weersma R, Khatun W, Chowdhury S, Begum A, et al. Risk factors of mortality in severely-malnourished children hospitalized with diarrhoea. J Health Popul Nutr. 2011;29(3):229-235.

24. Savadogo LGB, Zoebata I, Ilboudo B, Kinda M, Donnen P. Impact of anemia on mortality and nutritional recovery among hospitalized severely malnourished children in Burkina Faso. Open Joutnal of Pediatrics. 2014;4:115-20.

25. Robertson SA. Simple acid-base disorders. Vet Clin North Am Small Anim Pract. 1989;19(2):289-306.

26. Odey FA, Etuk IS, Etukudoh MH, Meremikwu MM. Hypokalaemia in children hospitalised for diarrhoea and malnutrition in Calabar, Nigeria. Niger Postgrad Med J. 2010;17(1):19-22.

27. Shah GS, Das BK, Kumar S, Singh MK, Bhandari GP. Acid base and electrolyte disturbance in diarrhoea. Kathmandu Univ Med J (KUMJ). 2007;5(1):60-62.

28. Samsuria IK. The relationship between sodium, potassium, and hypothyroidism in Chronic Kidney Disease (CKD) patients. Bali Medical Journal. 2019;8(1):264-266.

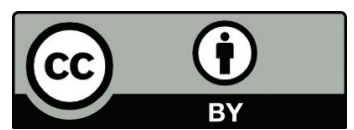

This work is licensed under a Creative Commons Attribution 